\title{
Correction to: Will the wind associated with the Adriatic storm surges change in future climate?
}

\author{
Iva Međugorac ${ }^{1}$ (D) $\cdot$ Mira Pasarić ${ }^{1}$ (D) $\cdot$ Ivan $^{\text {Güttler }}{ }^{2}$ (I)
}

Published online: 14 October 2020

(C) Springer-Verlag GmbH Austria, part of Springer Nature 2020

\section{Correction to: Theoretical and Applied Climatology} https://doi.org/10.1007/s00704-020-03379-x

1. In the original version of this article the authors unfortunately failed to state the source of sea-level data at Venice

We acknowledge that the used sea levels observed at station Venice Punta Salute are publicly available and were downloaded from the web page of the Tide Monitoring and Forecast Center in Venice (https://www.comune. venezia.it/node/6214).

The online version of the original article can be found at https://doi.org/ $10.1007 / \mathrm{s} 00704-020-03379-\mathrm{x}$

Iva Međugorac

ivamed@gfz.hr

Mira Pasarić

mpasaric@gfz.hr

Ivan Güttler

ivan.guettler@ cirus.dhz.hr

1 Department of Geophysics, Faculty of Science, University of Zagreb, Horvatovac 95, 10000 Zagreb, Croatia

2 Croatian Meteorological and Hydrological Service, Grič 3, 10000 Zagreb, Croatia
2. Table 1 contains mistakes and is not properly organized. The Table 1 should be as below. 
Table 1 Sea-level series and wind fields from different datasets. The first column shows used data: measured sea level and wind from reanalysis and simulations carried out with three regional climate models forced with different global climate models. Data are available for intervals listed in columns $2-4$, while temporal and spatial resolution of the data series are given in the last two columns

\begin{tabular}{|c|c|c|c|c|c|}
\hline Data/models & $\begin{array}{l}\text { Measurements/ } \\
\text { reanalysis/evaluation }\end{array}$ & Historical period & $\begin{array}{l}\text { Projections } \\
\text { RCP4.5/RCP8.5 }\end{array}$ & $\begin{array}{l}\text { Temporal } \\
\text { resolution (hour) }\end{array}$ & $\begin{array}{l}\text { Spatial } \\
\text { resolution }(\mathrm{km})\end{array}$ \\
\hline Sea level (Venice/Bakar) & 1984-2014 & & & 1 & \\
\hline ERA5 & 1984-2014 & & & 3 & $\sim 30$ \\
\hline \multicolumn{6}{|l|}{ ALADIN52 } \\
\hline - CNRM-CM5 & 1984-2012 & $1971-2000$ & $2041-2100$ & 3 & 12.5 \\
\hline \multicolumn{6}{|l|}{ RCA4 } \\
\hline $\begin{array}{l}\text { - CNRM-CM5 } \\
\text { - MPI-ESM-LR } \\
\text { - HadGEM2-ES } \\
\text { - EC-EARTH } \\
\text { - IPSL-CM5 }\end{array}$ & 1984-2010 & $1970-2005$ & $\begin{array}{l}2041-2100 \\
2041-2100 \\
2041-2099 \\
2041-2100 \\
2041-2100\end{array}$ & 6 & 12.5 \\
\hline \multicolumn{6}{|l|}{ RegCM4 } \\
\hline $\begin{array}{l}\text { - CNRM-CM5 } \\
\text { - MPI-ESM-MR } \\
\text { - HadGEM2-ES } \\
\text { - EC-EARTH }\end{array}$ & 1984-2014 & $1970-2005$ & $2041-2070$ & 3 & 12.5 \\
\hline
\end{tabular}

Publisher's note Springer Nature remains neutral with regard to jurisdictional claims in published maps and institutional affiliations. 